\title{
Infância como Conceito / Childhood as a Concept
}

https://doi.org/10.21814/uminho.ed.36.36

\section{Nigel Patrick Thomas}

University of Central Lancashire, UCLAN -School of Social Work, United Kingdom 



\section{Infância como Conceito}

A infância é um conceito que, à primeira vista, pode parecer simples e direto, mas numa análise mais fina revela-se complexo. 0 termo é frequentemente usado para referir um momento na vida de uma pessoa, em relação a um indivíduo ou grupo. Adquire particular ênfase a experiência de ser criança e viver no mundo de uma criança, ver através da perspetiva de uma criança e ser tratado por outros de maneiras "adequadas" a uma criança (como nas memórias de Tolstoy, Infância, Adolescência e Juventude, por exemplo). Tais reflexões podem ser positivas, eventualmente idealizadas, ou podem ser negativas, até mesmo assustadoras.

Este uso do termo "infância" como uma fase da vida é relevante na sociologia, assim como no discurso leigo. Os sociólogos contam histórias sobre a infância. Os sociólogos têm teorias, ou às vezes hipóteses não declaradas, sobre como é o momento da infância. Mais relevante na sociologia, entretanto, é o uso da infância para representar uma categoria social. As crianças são concebidas como distintas, até mesmo opostas, dos adultos - seja por não se considerarem exatamente como pessoas ou simplesmente como um tipo diferente de pessoa. Essa distinção pode assumir múltiplas formas.

A infância é muitas vezes diferenciada da fase adulta com base no que podemos chamar amplamente de termos "biológicos", com destaque para as diferenças físicas, como o tamanho ou a força e as características psicológicas, seja a capacidade cognitiva ou o desenvolvimento emocional. No passado, essa era a forma predominante de compreender a infância. Contudo, desde os anos 1970 e 1980, esta perspetiva tende a ser suplantada, pelo menos explicitamente, por uma compreensão baseada na infância enquanto construção social. Esta nova compreensão foi muitas vezes inspirada pela análise histórica de Philippe Ariès, mas o argumento sociológico não depende de evidências históricas; tampouco de evidências de variação cultural, embora também haja bastante disso nos estudos sobre as crianças.

Compreender a infância como uma construção social é prestar atenção aos limites e às características da infância, à maneira como são colocados em prática esses limites e caraterísticas através das formas como as pessoas se comportam e falam umas com as outras. É considerar que a infância é 
o que é e que as vidas das crianças são estruturadas como são, como um resultado do discurso, da cultura, das crenças, das leis e das práticas. Isso significa que poderia ser diferente; não está gravado em pedra nem é um dado natural; em essência, não existe uma infância.

Esta posição parece lógica, mas apresenta alguns problemas. 0 primeiro é que parece ignorar inteiramente a dimensão biológica. Assim, fica por explicar a aparente coincidência de que alguma forma da infância parece estar na estrutura social em sociedades largamente separadas no tempo e no espaço (uma abordagem realista crítica pode oferecer uma resolução para isso, incorporando a construção social em outros níveis de realidade). Outro problema é que, ao definir a Sociologia da Infância como um campo, muitas vezes parece necessário usar limites de idade que já foram reconhecidos como socialmente construídos, contingentes, e até arbitrários. Quer este seja ou não um problema real e substancial, é certamente um paradoxo.

Usar o conceito de infância na prática como um instrumento de análise sociológica levanta duas outras questões interessantes, ambas amplamente debatidas. A primeira é abrangida na frase "ser ou tornar-se". Os primeiros críticos da "socialização" ou dos modelos de desenvolvimento contestaram que as crianças eram posicionadas somente como futuros sujeitos e que a sua realidade como atores sociais no presente era ignorada. Isso inicialmente produz um discurso um tanto dicotómico, que se torna mais diferenciado com o reconhecimento de que todos, criança ou adulto, estão num processo contínuo de mudança e crescimento e, ao mesmo tempo, estão a viver uma vida no presente.

A segunda questão é saber se é mais oportuno ver a criança como um fenómeno único ou múltiplo, contido na frase "uma infância ou várias infâncias". A resposta depende em parte se o foco está na infância como uma componente da estrutura social ou na infância como uma prática. Procurar uma resposta definitiva não é importante, tanto quanto manter a questão viva através de diferentes tipos de investigação sociológica. No final, a "infância" é mais útil para a sociologia como um conceito crítico, usado para fazer perguntas sobre sociedades e contextos sociais, e, desta forma, ele mesmo sujeito a crítica contínua.

(Tradução de Luana Dias Gonzaga) 


\section{Childhood as a Concept}

Childhood is a concept that at first sight may appear simple and straightforward, but on closer examination becomes rather more complicated. The term is often used to refer to a time in one's life, in relation to an individual or to a group, with an emphasis perhaps on the experience of being a child and living in a child's world, seeing from a child's perspective, and being treated by others in particular ways as "befitting" a child (as with Tolstoy's memoir Childhood, Boyhood, Youth, for example). Such reflections may be positive, even idealised, or they may be negative, even horrifying.

This use of the term "childhood" as a life phase is relevant in sociology as well as in lay discourse. Sociologists tell stories about childhood. They have theories, or sometimes unstated assumptions, about what the time of childhood is like. More salient in sociology, however, is the use of childhood to represent a social category. Children are conceived as distinct from, even defined as in opposition to, adults - whether that be as not-quite persons, or merely as a different kind of person. That distinction can take several different forms.

Childhood is often distinguished from adulthood in what we may call broadly "biological" terms, with the emphasis on physical differences such as size or strength, and on psychological characteristics such as cognitive ability or emotional development. In the past, this was the dominant way of understanding childhood, but since the 1970s and 1980s it has tended to be supplanted, explicitly at least, by an understanding based on social construction. This understanding has often been inspired by the historical analysis of Philippe Ariès, but the sociological argument is not dependent on evidence from history; nor indeed on evidence of cultural variation, although there is much of that too.

To understand childhood as a social construction is to pay attention to the ways in which the boundaries, and the characteristics, of childhood are set in practice by the ways in which people behave and talk to each other. It is to consider that childhood is what it is, and that children's lives are structured as they are, as an outcome of discourse, of culture, of beliefs, of laws and of practices. This means that childhood could be different; it is not set in stone, or naturally given; there is no essential childhood.

This understanding seems logical, but it comes with a few problems. The first is that it appears to ignore the biological dimension entirely, and 
therefore struggles to explain the apparent coincidence that some form of childhood seems to appear in the social structure in societies widely separated in time and space. (A critical realist approach may offer a resolution to this, by embedding social construction within other levels of reality.) Another problem is that, in defining the sociology of childhood as a field, it often appears necessary to use boundaries of age that have already been recognised as socially constructed, contingent, even arbitrary. Whether or not this is a real and substantial problem, it is certainly a paradox.

Using the concept of childhood in practice as a tool of sociological analysis raises a couple of other interesting questions, both of which have been much debated. The first is encapsulated in the phrase "being or becoming". Early critics of "socialisation" or developmental models objected that children were positioned solely as future persons and that their reality as social actors in the present was ignored. This initially produces a rather dichotomous discourse, which has become more nuanced with the recognition that everyone, child or adult, is in a continual process of change and growth, and at the same time is living a life in the present.

The second question is whether it is more helpful to see childhood as a single or multiple phenomenon, captured by the phrase "one childhood or many childhoods". The answer depends in part on whether the focus is on childhood as a component of the social structure or on childhood as a practice. Seeking a definitive answer is not important, so much as keeping the question alive through different types of sociological inquiry. In the end "childhood" is most useful to sociology as a critical concept, used to ask questions about societies and social settings, and itself subjected to continual critique.

\section{Referências / References}

James, A., Jenks, C. \& Prout, A. (1998). Theorizing Childhood. Cambridge: Polity Press.

Qvortrup, J. (2017). Macro-analysis of childhood. In P. Christensen, \& A. James, A. (Eds.), Research with Children: Perspectives and Practices (pp. 77-97). London: Routledge.

Spyrou, S. (2018). Disclosing Childhoods: Research and Knowledge Production for a Critical Childhood Studies. Basingstoke: Palgrave. 